\title{
EXPERIMENTAL SUBSTANTIATION OF AUTOPLASMA APPLICATION AS A HAEMOSTATIC AGENT IN ENDOSCOPIC OPERATIONS IN THE DIGESTIVE TRACT
}

Tatiana V. Bochkova, Shamil Kh. Gantsev

Bashkir State Medical University

\author{
EKSPERIMENTALNI DOKAZ O PRIMENI AUTOPLAZME KAO \\ HEMOSTATSKOG AGENSA KOD ENDOSKOPSKIH OPERACIJA U \\ DIGESTIVNOM TRAKTU \\ Tatiana V. Bochkova, Shamil Kh. Gantsev \\ Baškir državni medicinski univerzitet
}

\begin{abstract}
Introduction. In endosurgery of the digestive tract, 'cellular technologies' are gaining popularity, including the use of blood components or blood cells with a haemostatic purpose. In this regard, the objective of the study is evaluation of the effectiveness of bleeding control and safety of resection of the hollow organs of the digestive tract in the experimental trauma models of the abdominal organs in laboratory animals. Materials and methods. The study was conducted in 20 mature male Chinchilla rabbits with the mean body mass of $2450 \pm 210 \mathrm{~g}$. All animals were divided into four experimental groups: the control group (without bleeding control); the group that received the infiltration of the wall of a hollow organ with saline; the group in which bleeding was controlled by argon plasma coagulation (APC), and the group wherein animals underwent haemostasis with autoplasma. Results. In the control group and the physiological saline group, no statistical difference was observed in the time of bleeding control. Autoplasma, due to preventive local administration, is more effective than APC and has a high haemostatic potential. Conclusion. Autoplasma has been found to be highly effective and safe for bleeding control in the gastrointestinal tract in the experimental model, which has paved the way for new possibilities for operations of various scales, including endoscopic operations.

Keywords: bleeding; hemostasis; autoplasma
\end{abstract}

\section{SAŽETAK}

Uvod. U endohirurgiji digestivnog trakta, „,celularne tehnologije“ dobijaju na popularnosti, uključujući upotrebu krvnih komponenti ili krvnih ćelija u hemostatsku svrhu. U ovom pogledu, cilj studije je procena efikasnosti kontrole krvarenja i bezbednosti resekcije šupljih organa digestivnog trakta na eksperimentalnim modelima traume abdominalnih organa kod laboratorijskih životinja. Materijali i metode. Studija je sprovedena na 20 odraslih mužjaka činčila zečeva sa prosečnom telesnom teži-

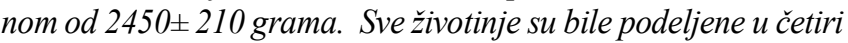
eksperimentalne grupe: kontrolna grupa (bez kontrole krvarenja), grupa u kojoj je izvršena infiltraciju zida šupljeg organa sa fiziološkim rastvorom, grupa u kojoj je krvarenje kontrolisano pomoću argon plazma koagulacije (APC) i grupa u kojoj su životinje bile podvrgnute hemostazi sa autoplazmom. Rezultati. U kontrolnoj grupi i grupi sa fiziološkim rastvorom nije bila primećena statistička razlika u vremenu kontrole krvarenja. Autoplazma zbog preventivne lokalne primene je efikasnija nego APC i ima visok hemostatski potencijal. Zaključak. Za autoplazmu je pronađeno da je veoma efikasna i bezbedna za kontrolu krvarenja u gastrointestinalnom traktu na eksperimentalnom modelu što je utrlo put novim mogućnostima za operacije različitih dimenzija uključujući endoskopske operacije.

Ključne reči: krvarenje, hemostaza, autoplazma

\section{sciendo}

DOI: $10.2478 /$ sjecr-2020-0033
Corresponding author: Tatiana V. Bochkova, MD, PhD ulica Lenina 3, 450008 Ufa, Russia E-mail: bochkova72@rambler.ru 


\section{INTRODUCTION}

Currently, most medical technologies in abdominal surgery involve removal of pathologically altered tissues. Any surgical intervention is associated with complications, among which the most frequent and threatening are perforation of the hollow organ and bleeding. At present, physical methods of haemostasis are widely used in endosurgery, creating comfortable conditions for performing the operation and obtaining, in general, positive results (1). However, it should be noted that 'cellular technologies' are gaining popularity in endosurgery of the digestive tract, including the use of blood components or blood cells with a haemostatic purpose. There are reports that the use of these blood components allows optimizing local haemostasis with the maximum efficiency, and it improves conditions for surgical dissection, preventing perforation of the hollow organs (2-4). P.S. Randelli et al note that the use of auto plasma during the arthroscopic treatment of injuries to the rotatory cuff of the shoulder can statistically reduce the intensity of pain in all patients (5). G. Filardo et al obtained a good clinical result when using autoplasma to treat athletes suffering from tendinitis of their own patellar ligament (6). However, available literature data on the efficacy and safety of the use of blood autologous components at local applications are contradictory. In this regard, the objective of the study is to evaluate the effectiveness of bleeding control and safety of resection of the hollow organs of the digestive tract in the experimental trauma models of the abdominal organs in laboratory animals.

\section{MATERIALS AND METHODS}

All experimental work was performed at the premises of the Oncology Research Institute of Bashkir State Medical University (BMSU) following the national recommendations of the 'Guidelines for the Preclinical Study of New Pharmacological Substances,' good laboratory practice (GLP) and international ethical standards and rules (7). The study was approved by the ethics committee of Bashkir State Medical University (protocol No.10 of February 11, 2018).

The study was conducted using 20 mature male Chinchilla rabbits with the mean body mass of $2450 \pm 210 \mathrm{~g}$. Animals were quarantined for 7 days in a separate box of vivarium of BMSU. The animals had a full-time free access to drinking bowls, received a set of natural products (vegetables and grain) and a standard diet, presented in the form of extruded pelleted feed for the housed laboratory animals.

All animals were divided into four experimental groups (five animals each): I-the control group that did not use any methods of bleeding control, II-the group that received infiltration of the hollow organ wall with physiological saline, III-the group that underwent physical haemostasis by the electrosurgical unit and argon plasma coagulation (APC) apparatus and IV-the group of animals that underwent local biologically controlled haemostasis using autoplasma. To receive autoplasma, the whole blood collection was performed from the rabbit's ear in the amount of $2 \mathrm{ml}$ before laparotomy. For a stabilizer, sodium citrate was used in the ratio of 1:9 with blood. The blood was centrifuged at $1500 \mathrm{rpm}$ for 5 $\mathrm{min}$. The ready-to-use autoplasma was injected into a zone of the prospective resection of mucosa of the rabbit's digestive tract. The group of intact animals was included in the experiment to compare the condition and behaviour of these animals with experimental animals.

Under general anaesthesia (Zoletil 7 mg/kg, Virbac Sante Animale, France), after preparation of the surgical field (shaving and aseptic treatment), laparotomy and mobilization of the stomach, duodenum and colon were performed. The main studies in the stomach were carried out in a zone of the body and its antrum where anatomically good and intense blood circulation was observed. Next, the bleeding was caused by a scalpel transversely crossing the intestine. The time to bleeding control was recorded by a stopwatch and evaluated visually.

The results of the study were processed using the statistical package Statistica 10.0 (StatSoft Inc, USA). The test for normality of distribution of the actual data was performed using the Shapiro-Wilk test. It was determined that the type of distribution of the obtained data differs from the normal one; therefore, in further analysis, we used nonparametric methods. The data are presented as medians (Me), 25 and 75 percentiles. The analysis of variance was performed using the Kruskal-Wallis test. The significance level p for statistical criteria was taken equal to 0.05 .

\section{RESULTS}

The results of evaluating the effectiveness of different methods of bleeding control in the experiment are presented in Table 1.

In the control group (I) and in the physiological saline group (II), there was no statistical difference in the time of bleeding control; however, in the group II, one more episode of bleeding was seen. The data presented in Table 1 demonstrate that autoplasma has a high haemostatic potential following the preventive local administration (group IV) (Figure 1). 
Table 1. The main indicators of the results of bleeding control in the studied groups of laboratory animals, $\mathrm{Me}(0.25-0.75)$

\begin{tabular}{|c|c|c|c|c|}
\hline Group & I & II & III & IV \\
\hline $\begin{array}{c}\text { Time to } \\
\text { bleeding } \\
\text { control, s }\end{array}$ & $\begin{array}{c}147.2 \\
(140.4- \\
153.6)^{\#, \dagger}\end{array}$ & $\begin{array}{c}130.1 \\
(120.5- \\
145.8)^{\#,} \\
\dagger\end{array}$ & $\begin{array}{c}89.6 \\
(85.4- \\
100.2)^{*} \\
\dagger\end{array}$ & $\begin{array}{c}17.8 \\
(15.4- \\
20.7)^{*, \#, \dagger}\end{array}$ \\
\hline $\begin{array}{c}\text { Recurrent } \\
\text { bleeding, } \\
\text { abs. (\%) }\end{array}$ & $\begin{array}{c}2(16.7) \\
\#,+\end{array}$ & $\begin{array}{c}1(8.3)^{*}, \\
\#,+\end{array}$ & $0(0.0)^{*}$ & $0(0.0)^{*}$ \\
\hline
\end{tabular}

Medians of the bleeding time for all injured organs $(n=12)$ are presented. The level of statistical significance differs between the animal groups: * $\mathrm{p}<0.05$ - compared with the group I, \# p $<0.05$ - compared with the group III,

$\dagger \mathrm{p}<0.05$ - compared with the group IV.

Figure 1. Comparison of the intensity of bleeding when using autoplasma (A-administration of the drug, $\mathrm{B}$-intestinal dissection) with the control (C).


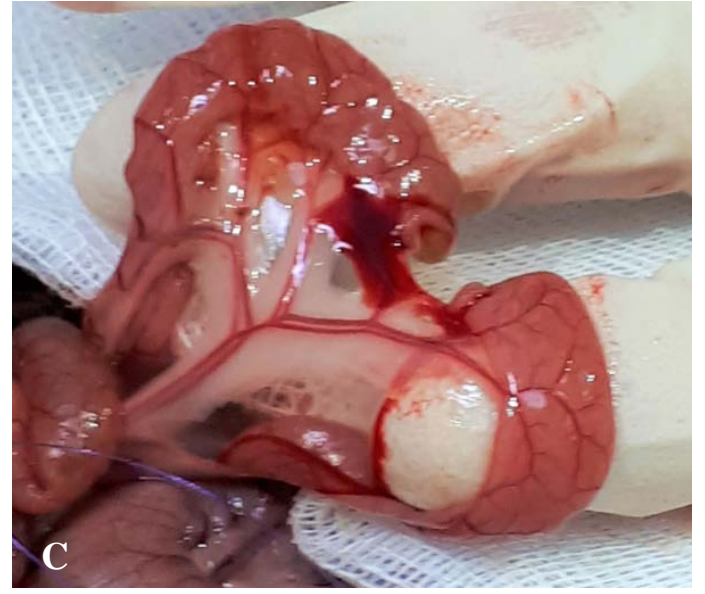

At the same time, electrocoagulation is expectedly more effective than physiological saline, but haemostasis with APC is characterized by the rapid formation of a necrotic zone, which may have unfavourable consequences in the future.

\section{DISCUSSION}

Till date, physical methods (clips, acupressure, coagulation, etc.) and non-contact coagulation agents (APC and local haemostatic agents) have been used for bleeding control (8). All physical methods for bleeding control require adequate visualization of the source for accurate positioning of the endoscope to the source of bleeding, adequate pressure on the tissue and sufficient duration of exposure for complete coagulation. Simultaneously, prolonged coagulation increases the risk of deep tissue damage and perforation, whereas insufficient pressure or duration of exposure can aggravate bleeding (9). The use of clips can also be difficult when placed on bleeding vessels at the bottom of a large fibrous ulcerative defect due to deficiency of the surrounding tissues (10). The disadvantages of endoscopic suture devices are their lack of accessibility, the need for a two-channel endoscope, technical complexity and limited manoeuvrability, making it difficult to access certain areas of the stomach (11).

Non-contact haemostatic devices such as APC and local haemostatic agents do not require clear positioning of the bleeding source, which greatly simplifies their use (12). Complications from APC are rare and include gastric distension with gaseous argon, submucosal emphysema, pneumomediastinum, pneumoperitoneum and perforation (10). A number of authors attribute these complications to technical errors during the procedure- - the probe's contact with the tissue, which causes the influx of argon gas into submucosa. This method is often ineffective-any fluid (for example, blood) between the probe tip and the bleeding tissue can cause formation of the coagulation film, which may interfere with the adequate surgical haemostasis (13). 
The benefits of topical haemostatic agents include their ease of use and potential efficacy in bleeding control at various sites $(14,15)$. One of the most common and inexpensive measures are injections of diluted adrenaline. Adrenaline injections contribute to primary haemostasis, but this effect gets depleted, with the subsequent risk of rebleeding. This haemostasis can be used to monitor initially active bleeding and improve visualization; it should be combined with another method to reduce the risk of rebleeding. Complications of the injection therapy are usually associated with the effects of the drug injected (10). Among the most threatening complications are tissue necrosis, ulceration and perforation, as well as hypertension, and cardiac arrhythmia $(13,16)$. Today, in addition to the injection therapy, which should not be used as monotherapy, there are few convincing data that would definitely give preference to specific methods of haemostasis. However, there are sufficient numbers of experimental and fundamental studies offering various synthetic drugs as systemic or local injection drugs (17-19). While these agents for local and systemic haemostasis are at different stages of preclinical and clinical studies, the effective alternative is to use autologous coagulation factors to increase haemostatic potential. The results of our study have demonstrated high efficiency and safety of autoplasma in bleeding control in the gastrointestinal tract in the experimental animals.

From the point of view of prevention of complications associated with perforations, there are also approaches that have proven their effectiveness in a large number of patients (12). However, our endosurgical experience allows us to note that not all classical methods, including electrosurgical, allow achieving the stable haemostasis in the wound sites of the digestive tract, given their high vascularization (20). We have observed that the 'lifting effect' used for the convenience of dissection gets exhausted rapidly, and its protective effect disappears. This, in turn, increases the risk of iatrogeny and possible complications.

\section{CONCLUSION}

In conclusion, high efficiency of autoplasma has been established for the bleeding control in the gastrointestinal tract in the experiment, which paves the way for new possibilities for operations of various scales, including endoscopic operations. The potential application of this method of bleeding and perforation prevention in patients with underlying disorders of the haemostatic system aiming to increase locally the content of coagulation factors should be emphasised.

\section{REFERENCES}

1. Alali A, Espino A, Moris M, Martel M, Schwartz I, Cirocco M, et al. Endoscopic resection of ampullary tumours: Long-term outcomes and adverse events. J Can Assoc Gastroenterol 2020; 3(1): 17-25.

2. Achkasov EE, Ul'ianov AA, Bezuglov EN. The use of autoplasma rich in platelet growth factors (APRPGF) on results of treatment of patients with pilonidal sinus abscess. Khirurgiia 2013; (12): 43-7.

3. Behrens AM, Sikorski MJ, Kofinas P. Hemostatic strategies for traumatic and surgical bleeding. J Biomed Mater Res A. 2014;102(11):4182-4194.

4. Lew WK, Weaver FA. Clinical use of topical thrombin as a surgical hemostat. Biologics. 2008;2(4):593-599.

5. Randelli PS, Arrigoni P, Cabitza P, Volpi P, Maffulli N. Autologous platelet rich plasma for arthroscopic rotator cuff repair. A pilot study. Disabil Rehabil. 2008;30(2022):1584-1589.

6. Filardo G, Kon E, Della Villa S, Vincentelli F, Fornasari PM, Marcacci M. Use of platelet-rich plasma for the treatment of refractory jumper's knee. Int Orthop. 2010;34(6):909-915.

7. Guidelines on pre-clinical study of pharmaceutical substances. Part one. Moscow: Grif and Co., 2012:944.

8. Wang TX, Zhang J, Cui LH, Tian JJ, Wei R. Efficacy of therapeutic endoscopy for gastrointestinal lesion (GI): A network meta-analysis. Pak J Med Sci 2019; 35(2): 5618.

9. Rajala MW, Ginsberg GG. Tips and tricks on how to optimally manage patients with upper gastrointestinal bleeding. Gastrointest Endosc Clin N Am 2015; 25: 607-17.

10. Parsi MA, Trindate AJ, Bhutani MS. Cryotherapy in gastrointestinal endoscopy. VideoGIE 2017; 2: 89-95..

11. Fujii-Lau LL, Wong Kee Song LM, Levy MJ. New technologies and approaches to endoscopic control of gastrointestinal bleeding. Gastrointest Endosc Clin N Am 2015; 25: 553-67.

12. Ghassemi KA, Jensen DM. Evolving techniques for gastrointestinal endoscopic haemostasis treatment. Expert Rev Gastroenterol Hepatol 2016; 10: 615-23.

13. Prei JC, Barmeyer C, Burgel N. EndoClot polysaccharide haemostatic system in nonvariceal gastrointestinal bleeding: results of a prospective multicenter observational pilot study. J Clin Gastroenterol 2016; 50: e95100.

14. Ghassemi KA, Jensen DM. Evolving techniques for gastrointestinal endoscopic haemostasis treatment. Expert Rev Gastroenterol Hepatol 2016; 10: 615-23.

15. Garcia de la Filia I, Hernanz N, Vazquez Sequeiros E. Recurrent gastrointestinal bleeding secondary to Dieulafoy's lesion successfully treated with endoscopic ultrasound-guided sclerosis. Gastroenterol Hepatol. 2017; 41: 319-20. 
16. Nabi Z. Complications of therapeutic gastroscopy/colonoscopy other than resection. Best Pract Res Clin Gastroenterol 2016; 30: 719-33.

17. Gurevich KG, Urakov AL, Bashirova LI, et al. The haemostatic activity of bis (2-aminoethan-1-sulfonate) calcium. Asian J Pharm Clin Res 2018; 11(11): 452-5.

18. Urakov AL, Samorodov AV, Kamilov FK, Khaliullin FA, Gubaeva RA. Haemostatical activity of new benzylammonium salt, 2-[3-methyl-1-n-propyl-7-(1,1-dioxotiethanyl-3)xantinyl-8-thio]acetic acid. Natl J Physiol Pharm Pharmacol 2017; 7(11): 1213-8.

19. Khaliullin FA, Shabalina YuV, Samorodov AV, Kamilov FKh, Timirkhanova GA, Murataev DZ. Synthesis and antiaggregant activity of 2-[3-Methyl-1-Ethylxanthinyl-8-Thio]acetic acid salts containing a thietane ring. Pharm Chem J 2018;52(1):29-32.

20. Panteleev V, Nartaylakov M, Mustafin A, et al. Surgical treatment of liver echinococcosis and alveococcosis. Infez Med. 2019;27(4):422-428. 